\title{
A Destroyer Immunologic Cause in Small Cell Lung Carcinoma: Ectopic Cushing's Syndrome
}

\author{
Küçük Hücreli Akciğer Kanserinde Yikıcı Bir Durum: Ektopik Cushing Sendromu \\ İrfan ÇIÇİN, Sernaz UZUNOĞLU, Nilay ERMANTAŞ, Ufuk USTA, ${ }^{1}$ Osman TEMİZÖZ, ${ }^{2}$ Hakan KARAGÖL \\ Departments of Medical Oncology, ${ }^{1}$ Pathology, ${ }^{2}$ Radiology Medical Faculty of Trakya University, Edirne
}

Submitted / Başvuru tarihi: 14.08.2008 Accepted/Kabul tarihi: 05.11.2008

Ectopic secretion of adrenocorticotropic hormone (ACTH) related Cushing's syndrome (CS) is more frequently observed than many other paraneoplastic syndromes in patients with small cell lung cancer. Suppression of the cellular immune system in these patients is severe problem for both patients and physicians. In addition, the chemotherapy has been caused to severity and higher rate of hematological toxicity. We present a case of small cell lung cancer having a very poor prognosis, with a compressed humoral and cellular immune system due to an ectopic secretion of ACTH related CS. We report a rare case of combined immunosuppression in a case with small cell lung cancer in this paper. In addition, in the light of this special case and literature, we suggest treatment strategies for small cell lung cancer patients with CS.

Key words: Cushing's syndrome; small cell lung cancer; immunosuppression.
Ektopik adrenokortikotop (ACTH) salınmasına bağlı Cushing sendromu, küçük hücreli akciğer kanserli hastalarda diğer birçok paraneoplastik sendromlara göre daha sık görülür. Bu hastalarda hücresel bağışıklık sisteminin baskılanması hem hekimler hem de hastalar için önemli bir sorundur. Ek olarak kemoterapi, bu hastalarda şiddetli ve daha yüksek oranda hematolojik toksisiteye neden olmaktadır. Biz ektopik ACTH salınması ile ilişkili Cushing sendromuna bağlı humoral ve hücresel bağışıklık sistemi baskılanmış çok kötü seyirli bir küçük hücreli akciğer vakası sunduk. Ayrıca, bu özel vaka ve literatür ışığında Cushing sendrom olan küçük hücreli akciğerli hastalar için tedavi stratejileri önerdik.

Anahtar sözcükler: Cushing sendromu; küçük hücreli akciğer kanseri; bağışıklık baskılanması.
Although Cushing's syndrome (CS) associated with the
ectopic secretion of adrenocorticotropin (ACTH) has
been reported in association with a variety of malignant
tumors, it has been seen more frequently in patients with
small cell lung cancer (SCLC). ${ }^{[1]}$ Opportunistic infections
are seen with increased frequency in patients with CS,
especially due to cellular immunosuppression. ${ }^{[2]}$ We
present a case of SCLC having a very poor prognosis,
with a suppressed humoral and cellular immune system and with an ectopic secretion of ACTH (EA) related CS presented with oral candidiasis. To our knowledge, we report the first case of combined immunosuppression in a case with small cell lung cancer in this paper.

\section{CASE REPORT}

A 37-year-old male having edema, weakness and agitation was admitted to our hospital in June 2006. He was a heavy smoker. On examination, mild mooning face, 
glossitis, curdy white patches on the lingue and palate were observed, and proximal muscle weakness was obtained. Laboratory was significant for hypokalemia and alkalosis (Table 1). A chest X-ray showed approximately $2.5 \mathrm{~cm}$ right central mass. We considered CS in the patient depending on these findings mentioned above. Indeed, it was confirmed by an elevated morning serum cortisol, ACTH levels and by the lack of ACTH suppression during high-dose $(8 \mathrm{mg})$ overnight dexamethasone suppression test (Table 1). Magnetic resonance of hypophysis was normal. A computed tomographic (CT) scan of thorax showed in the lung bilateral, solid masses some of which were necrosis (Fig. 1a). The adrenal glands were normal in an upper abdomen CT. A core biopsy was performed from lung and SCLC was diagnosed (Fig. 1b). His oral lesions were diagnosed as candidiasis. Due to CS and oropharyngeal candidiasis, we came to conclusion that his immunity could be affected. Tuberculin skin test was negative. CD4/CD8 rate and immunoglobin $\mathrm{G}$ and $\mathrm{M}$ levels were lower than those observed in the Turkish population. ${ }^{[3]}$ Human immunodeficiency virus (HIV) was negative. Based on

\section{Table 1. Hematologic, immunological and endocrine} test results

\begin{tabular}{|c|c|c|}
\hline Variable & First Values & $\begin{array}{l}\text { At the time } \\
\text { febril neutropenia } \\
\text { (10th day) values }\end{array}$ \\
\hline Hematocrit (\%) & 33.6 & 23.3 \\
\hline White-cell count (per $\mathrm{mm}^{3}$ ) & 9880 & 261 \\
\hline Neutrophils & 8790 & 122 \\
\hline Lymphocytes & 722 & 94 \\
\hline Platelet count (per $\mathrm{mm}^{3}$ ) & 230000 & 9810 \\
\hline Prothrombin time (sec) & 15.4 & 20.3 \\
\hline $\operatorname{IgG}(751-1560 \mathrm{mg} / \mathrm{dl})^{*}$ & 685 & - \\
\hline $\operatorname{IgM}(46-304 \mathrm{mg} / \mathrm{dl})^{*}$ & 36.5 & - \\
\hline $\operatorname{IgA}(82-453 \mathrm{mg} / \mathrm{dl})^{*}$ & 125 & - \\
\hline CD4 $\left(1095 \pm 391 \text { per } \mathrm{mm}^{3}\right)^{\star *}$ & 217 & - \\
\hline CD8 $\left(669 \pm 239 \text { per } \mathrm{mm}^{3}\right)^{\star \star}$ & 522 & - \\
\hline CD4/CD8 $(1.7)^{\star \star}$ & 0.42 & - \\
\hline Protein $(6.1-7.9 \mathrm{~g} / \mathrm{dl})$ & 5.8 & 4.3 \\
\hline Total Albumin $(3.5-5 \mathrm{~g} / \mathrm{dl})$ & 3 & 2 \\
\hline Sodium (136-144 mEq/ liter) & 143 & 139 \\
\hline Potassium (3.5-5 mEq/ liter) & 1.7 & 3.2 \\
\hline $\begin{array}{l}\text { Lactate dehydrogenase } \\
\text { (98-192 U/liter) }\end{array}$ & 372 & 380 \\
\hline Glucose $(70-110 \mathrm{mg} / \mathrm{dl})$ & 120 & 105 \\
\hline Cortisol $(5-25 \mu \mathrm{g} / \mathrm{dl})$ & 1527 & - \\
\hline АCTH $(0-46$ pg/ml) & 343 & - \\
\hline $\begin{array}{l}\text { Cortisol after ACTH suppresion } \\
\text { ( } 8 \mathrm{mg} \text { dexamethasone } \\
\text { suppression test })(\mu \mathrm{g} / \mathrm{dl})\end{array}$ & 1510 & - \\
\hline
\end{tabular}

\footnotetext{
${ }^{*}$ by using nepholometric method, ${ }^{* *}$ by using flowcytometry.
}

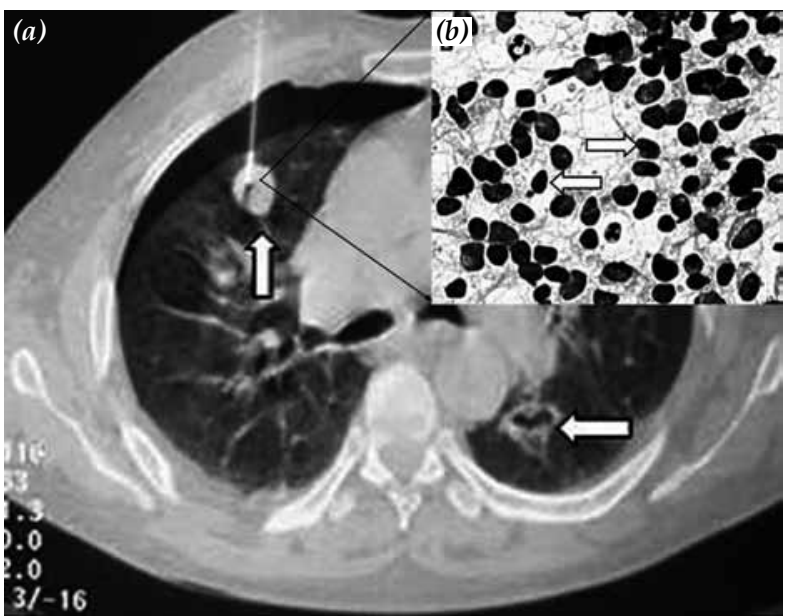

Fig. 1. (a) Bilateral solid masses some of which were necrosis showed in the lung. Iatrogenic pneumothorax emerged and core biopsy repetition. (b) Epithelial cells showing prominent nuclear pleomorphism, hyperchromasia tend to arrange haphazardly, rarely forming rosette like structures (arrows). Note the absence of nucleoli and absence of cytoplasm (PAPx400).

these results, cell mediated and humoral immunodeficiency was diagnosed. For the treatment of CS and oral candidiasis, $200 \mathrm{mg}$ oral ketocanozole was administered twice a day. In addition, for oral candidiasis, nistatin oral suspension was prescribed. Chemotherapy (cisplatin 75 $\mathrm{mg} / \mathrm{m} 2$ on first day; etoposide $125 \mathrm{mg} / \mathrm{m} 2$ on 1 st-3rd days) was immediately started to control both the tumor and CS. The patient refused to stay in hospital after chemotherapy. On the ninth day, he was interned with febrile neutropenia (Table 1). Ceftazidime $2 \mathrm{gr}$ IV three times a day and ciprofloxacin $200 \mathrm{mg}$ IV twice a day and granulocyte-colony stimulating factor (G-CSF) $48 \mathrm{mU} /$ day were applied. Klebsiella pneumoniae was observed in his blood culture. Despite the intensive care, the patient died after two days.

\section{DISCUSSION}

Clinical CS secondary to EA occurs in approximately $5 \%$ of all SCLC patients and is a poor prognostic factor. Typically, EA related CS is suspected when a patient with a known malignancy has refractory hypokalemia and metabolic alkalosis. However, EA related CS presents throughout the life span with variable features including psychiatric, infectious, orthopedic, reproductive, and nonspecific systemic complaints. The malignant character of the underlying neoplasm often influences the clinical presentation. As a result, patients may present to clinicians of many specialties, and recognition of the disorder may be delayed. ${ }^{[1,2]}$

Several case studies have suggested an association between EA related CS and the risk of life-threatening infection. High circulating levels of endogenous cortisol mainly affect cellular immunity qualitatively through 
functional impairment of many effector immune cells, such as T lymphocytes, granulocytes, and monocytes and macrophages. Delayed type hypersensitivity is severely impaired, and anergy is common. Recent studies have also demonstrated the effect of glucocorticoids on the humoral immune system. Conversely, G-CSF and granulocyte-macrophage (GM)-CSF could be prevented suppression of granulocytes and macrophages in the presence of glucocorticoids. ${ }^{[3]}$

Among the endogenous CS subtypes, severe infections are much more prevalent with ectopic ACTH production because of highest levels of glucocorticoid excretion. ${ }^{[4]}$ Graham et al. ${ }^{[4]}$ reported that there are different cortisollevel thresholds for each different infection in patients with endogenous CS. Other authors have suggested that prophylactic antibiotherapy for Pneumocystis carinii pnuemonitis should be initiated when cortisol levels exceed 2486 $\mathrm{nmol} / \mathrm{L} \cdot{ }^{[5]}$ Sarlis et al. ${ }^{[6]}$ showed that high levels of endogenous glucocorticoids, are reliable indicators for predicting severe infections in patients with untreated EA-related CS, but not white blood cell counts or temperature. In addition, Sheperd et al. ${ }^{[7]}$ show that significant hematologic toxicity was encountered after chemotherapy. The median nadir granulocyte count was only $0.24 \times 109 / \mathrm{L}$, and $25 \%$ patients had nadir granulocyte counts of zero in with EA-related CS due to SCLC in their study. Dimopoulos et al. ${ }^{[8]}$ reported that the median survival from initiation of chemotherapy was 12 days for patients with CS. In $45 \%$ of the patients with CS, death was attributed to opportunistic fungal or protozoal infection compared with $8 \%$ of control patients.

Immunosuppression associated with endogenous CS appears reversible with treatment of the underlying condition. Prompt correction of hypercortisolism with pharmacology or surgery usually resolves infections and greatly reduces the risk of recurrence. Therefore, early diagnosis of CS with prompt initiation of treatment to reduce cortisol levels is recommended. ${ }^{[9]}$

We observed that humoral and cell mediated immune system were suppressed in a patient with EA related CS due to SCLC. However, to our researches, there is not publication regarding low gammaglobulins levels related to CS in the literature. On the other hand, there were not any other findings, which were likely to show other etiological factors for hypogammaglobulinemia. It is possible that proliferation and differentiation of $B$ cells and their antibody production which can appear as a result of $\mathrm{T}$ helper (Th) 2 function may be suppressed in the CS, because glucocorticoids cause Th1/Th2 dysregulation. ${ }^{[10]}$ In the light of this special case and literature, we suggest that:

- Each case with SCLC should be carefully examined for EA related CS because of its relatively high rate (approximately $1 / 20$ ).

- Each patient with EA related CS should be examined for immunosuppression. In the case of patients suffering from opportunistic infections such as candidiasis and varicella, physicians should particularly considered immunosuppression.

- In these patients carrying a high risk of fatal infections, prophylactic GCS-F should be used together with chemotherapy because of the high rate risk of severe granulocytopenia.

- As the lowering of the endogenous steroid level will reduce the complication risks, a suitable treatment of CS should be applied.

- In case of high level of ACTH, prophylactic trimethoprim-sulfametaksazol may be applied to prevent pneumonia of the Pneumocystis carinii.

- These patients should be interned until a tumor and endocrine response is achieved because of the high fatal complication risk.

\section{REFERENCES}

1. Kirk LF Jr, Hash RB, Katner HP, Jones T. Cushing's disease: clinical manifestations and diagnostic evaluation. Am Fam Physician 2000;62:1119-27.

2. Ilias I, Torpy DJ, Pacak K, Mullen N, Wesley RA, Nieman LK. Cushing's syndrome due to ectopic corticotropin secretion: twenty years' experience at the National Institutes of Health. J Clin Endocrinol Metab 2005;90:4955-62.

3. Lionakis MS, Kontoyiannis DP. Glucocorticoids and invasive fungal infections. Lancet 2003;362:1828-38.

4. Graham BS, Tucker WS Jr. Opportunistic infections in endogenous Cushing's syndrome. Ann Intern Med 1984;101:334-8.

5. Bakker RC, Gallas PR, Romijn JA, Wiersinga WM. Cushing's syndrome complicated by multiple opportunistic infections. J Endocrinol Invest 1998;21:329-33.

6. Sarlis NJ, Chanock SJ, Nieman LK. Cortisolemic indices predict severe infections in Cushing syndrome due to ectopic production of adrenocorticotropin. J Clin Endocrinol Metab 2000;85:42-7.

7. Shepherd FA, Laskey J, Evans WK, Goss PE, Johansen E, Khamsi F. Cushing's syndrome associated with ectopic corticotropin production and small-cell lung cancer. J Clin Oncol 1992;10:21-7.

8. Dimopoulos MA, Fernandez JF, Samaan NA, Holoye PY, Vassilopoulou-Sellin R. Paraneoplastic Cushing's syndrome as an adverse prognostic factor in patients who die early with small cell lung cancer. Cancer 1992;69:66-71.

9. Würzburger MI, Prelević GM, Brkić SD, Vucković S, Pendić B. Cushing's syndrome--transitory immune deficiency state? Postgrad Med J 1986;62:657-9.

10. Cenci E, Perito S, Enssle KH, Mosci P, Latgé JP, Romani L, et al. Th1 and Th2 cytokines in mice with invasive aspergillosis. Infect Immun 1997;65:564-70. 